pleasant than in the olden days, there are few long sea trips and the vessels themselves are so well equipped in every way. Every battleship now has its cold storage rooms, and fresh meats and provisions are as common as they used to be scarce; ice is fairly plentiful and so is fresh water, trained cooks have supplanted the old "mess cook" and fresh bread is baked daily and the food supplied is better than at many boarding houses. Salt horse and hard tack are now largely curiosities and there is a howl from the crew if pie is not served them at least three times a week. In other personal comforts things have changed for the better; the ventilation is good and the sleeping quarters of the apothecary is equipped with a comfortable bunk, he has electric lights to read by and can take a shower bath whenever he wants to. Even in amusements times have changed. Our music, if we had any, was afforded by amateur talent on accordeon or banjo, but the apothecary today can listen to the latest ragtime, or play it himself, on a player piano while most of the ships have their own band. Each ship now carries an excellent library, newspapers and magazines are frequent and mails are frequent, something we oldtimers were deprived of. I could go on this way recalling contrasts and incidents for hours but $I$ am afraid that $I$ have already taken up too much time with reminiscences which however interesting to me may not be thought so by others, so will bring my "log" to a close. Just one more word-if the times have changed and methods with them, the naval apothecary has kept up with the Navy and the men of today are just as skilled and highly trained as those of any other branch of the service. The naval apothecary doesn't carry sails now either.

\title{
IMPORTANT DATES IN THE CHRONOLOGY OF PHARMACY.
}

JOHN F. LLEWELLYN, MEXico, Mo.

B. C. 3500 . Is date of the oldest prescription, written on Egyptian stone, which is in the Metropolitan Museum of Art, N. Y.

B. C. 2000. Chinese knew Rhubarb, Aconite, Bark of Pomegranate, Ergot of Rye, Camphor, and Canella.

B. C. 2100. King Osimandias (Egypt) wrote above his library "The pharmacy of the soul," another rendering is "The office of remedies for diseases of the soul."

About this period pharmacy was separated from medicine in Egypt.

B. C. 1700 to 1400 . There are three Egyptian papyrus, that are as much pharmacopoeias as medical treatises, one mentions fifty vegetable substances, another sixty, that were used medicinally, besides those from animals and minerals.

Ointments, clysters, and poultices are mentioned.

They appealed to the god who will "slay the slayer."

B. C. 1490 and 1000 . The Bible mentions the art of the apothecary or perfumer. Moses probably had this from papyrus mentioned above, which he is supposed to have studied.

Apothecary and perfumer were one in Egypt. 
B. C. 1300 . Chiron, Esculapius and his two sons, this date is an average of nine estimates.

B. C. 460-327. Hippocrates.

B. C. 132-63. Mithriadates and his Mithridate or Theriac.

A. D. 50. Celsus wrote an account of the medical system of his time.

A. D. 65 . Pliny wrote a materia medica.

A. D. 100. Dioscerides wrote a treatise on materia medica and edited a pharmacopoeia.

A. D. 117. In Baden near Zurich there were found Roman ruins containing medical pharmaceutical and surgical appliances, medical spoons in bone and silver, measuring vessels, jars and pots, some containing traces of ointments; the latest coins found were those of Hadrian.

A. D. 130. Galen laid the foundation for galenicals.

A. D. 650 . The University of Salerno early in the seventh century taught pharmacy and the separation of medicine and pharmacy.

Nicholas Praepositus of Salerno wrote a pharmacopoeia.

Great advancement in pharmacy made at Salerno in the sixteenth century.

A. D. 750. Early in the eighth century Al Mansur established a pharmacy.

A. D. 806. Arabs produced a pharmacopoeia and established apothecary shops.

A. D. 829. Monastery of St. Gall had plans for a hospital and pharmacy.

A. D. 857. Schools of pharmacy arose in the chief Moslem cities.

Mesua became celebrated for his knowledge of drugs.

Mesua, the younger, of Damascus wrote "De Simplicis" which was used in forming the first English pharmacopoeia, 1618.

A. D. 949. Cordova made advancement in medicine greater than any since Galen.

Ibn Beytar the botanist, traveled all over the East to find medicinal herbs, on which he wrote an exhaustive treatise.

A. D. 1050. Monte Cassino, near Naples had a monastery hospital, infirmary and pharmacy.

A. D. 1145 . St. Hildegarde prepared a materia medica.

A. D. 1225. St. Elizabeth of Hungary established a sisterhood to nurse the sick and had a sisterhood pharmacy.

A. D. 1241. Frederick Domkellar presented his apothecary shop to the monastery of St. Thomas.

A. D. 1250. Established a drug store, privileges protected by government in Germany and France.

A. D. 1307. In Ragusa, Dalmatia is now a San Fransiscan pharmacy established in 1307. It has the pots and vases which held the herbs and simples from earliest times.

The labels burned into the pottery yet survive.

Ragusa claims to be the birthplace of Esculapius.

A. D. 1534. The Jesuits established pharmacies in their houses.

A. D. 1535. Henry VIII anused himself making cramp rings, plasters and compounding medicines.

He left a M. S. "A Book of Plasters, Spasm Drops, Ointments, and Poultices. Devysed by the King's Majestie (and four physicians)." 
A. D. 1535. A cousin of Anne Boleyn was an apothecary.

A. D. 1535. One of Cartier's crew was Francois Guileadt, "apotecaire."

A. D. 1540. The citizens of London agreed to buy for St. Bartholomew's Hospital all manner of apothecary wares and all that was necessary for making salves and all other things touching physic or surgery.

A. D. 1606. Louis Hebert, apothecary, came from France, and in 1616 returned and brought out his family.

A. D. 1613. Besler, a pharmacist of Nuremberg, published a work on botany.

A. D. 1625. Dalmahoy kept a shop on Ludgate Hill, where he sold drugs, potions, electuaries, powders, sweetmeats, wares for the complexion, scented hair oil pomades, dentifrices, love charms, Italian masks to sleep in, spermaceti salts, scammony and squills.

A. D. 1646. An apothecary of Boston obtained permission to build a paling.

A. D. 1698. An English physician reported Paris apothecary shops neat enough, if they were as well stored with medicines.

Some are finely adorned and have an air of greatness, vases of copper in niches of windows, within are mortars of brass as well for sight as use.

A. D. 1716. Douglas, an apothecary, was raised to the peerage, the wags said:

"In your arms rather quarter

A pestle and mortar

And your crest be a spruce gallipot."

A. D. 1729. Smithson, an apothecary, became a baron and son-in-law to a duke.

A. D. 1732. Thomas Harwood of Boston wrote a treatise on pharmacy.

A. D. 1785. Stark's Pharmacy, London, established, yet in business.

A. D. 1851. Organization of the American Pharmaceutical Association.

A. D. 1912. Publication of the Journal of the American Pharmaceutical Association.

A. D. 1912. Sixtieth anniversary of the A. Ph. A. 